\title{
Age-related changes of serum leptin, insulin, IGF-I and thyroid hormones levels in growing Jinhua and Landrace gilts
}

\author{
Z.G. Miao ${ }^{1,2}$, L.J. Wang1, Z.R. Xu ${ }^{1,3}$, X.Y. Han ${ }^{1}$, H.Z. Quan ${ }^{1}$ \\ and G.W. $\mathrm{Li}^{2}$
}

\author{
${ }^{I}$ Key Laboratory for Molecular Animal Nutrition of Ministry of Education, Institute of Feed \\ Science, Zhejiang University \\ HangZhou, 310029, P.R. China \\ ${ }^{2}$ College of Animal Science, Henan Institute of Science and Technology \\ XinXiang, 453003, P.R. China
}

(Received 5 March 2008; revised version 18 June 2008; accepted 27 October 2008)

\begin{abstract}
The present study was aimed to investigate the age-related changes of the serum IGF-I, leptin, insulin, triiodothyronine $\left(\mathrm{T}_{3}\right)$ and thyroxine $\left(\mathrm{T}_{4}\right)$ levels in pigs of different breeds. Jinhua and Landrace gilts were sampled at 35, 80 and 125 days of age, respectively. Serum hormone levels were measured with RIA. Serum IGF-I, leptin levels increased with age and displayed breed differences. Jinhua gilts showed lower $(\mathrm{P}<0.05)$ serum IGF-I and higher $(\mathrm{P}<0.05)$ leptin levels compared with Landrace gilts. In contrast, serum $\mathrm{T}_{3}, \mathrm{~T}_{4}$ levels decreased with age, Jinhua gilts had lower serum $\mathrm{T}_{4}$ levels at 80 days of age. Meanwhile, Jinhua gilts had higher $(\mathrm{P}<0.01)$ serum insulin levels. Serum leptin, IGF-I, insulin and $\mathrm{T}_{4}$ levels correlated with carcass fat content $(\mathrm{P}<0.05)$, which suggested that the breed differences of serum hormone levels may contribute to the different phenotypes in adipose tissue deposition.
\end{abstract}

KEY WORDS: gilts, leptin, insulin, IGF-I, thyroid hormones, age-related changes

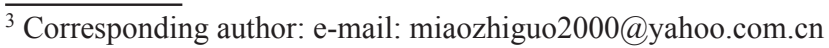




\section{INTRODUCTION}

The Jinhua pig is one of the most important Chinese local variety characterized by high reproductive performance, but low growth rate and strong fat deposition (Xu,1994). Landrace pigs are known by high growth rate, but low fat deposition and poor reproductive performance. Therefore, these two breeds of pigs can serve as ideal models for studying adipose tissue deposition of pigs. Fat deposition in adipose tissue, which represents a balance between fat synthesis and fat degradation (Chilliard, 1993), is regulated by hormonal factors and non-hormonal factors. Zhou et al. (2003) reported that GH-R and IGF-I mRNA expressions in adipose tissue were different between Erhualian and Large White pigs, suggesting the participation of GH/IGF-I axis in the regulation of fat deposition in the pig. The protein product of the $\mathrm{Ob}$ gene named leptin, is secreted mainly by white adipose tissue (Zhang et al., 1994). Numerous studies indicate that serum letpin concentration is highly correlated with fat deposition (Cameron et al., 2000), and serves as a signal reflecting the body fat content (Gill et al., 1997). In addition, thyroid hormones affect synthesis, mobilization and degradation of lipids (Pucci et al., 2000), insulin is mainly to stimulate glycogen synthesis, fatty deposition and inhibit gluconeogenesis (Ehterton et al., 1982; Chung et al., 1983). Because of the breed difference in growth potential, the developmental changes of hormones concentrations related to adipose deposition may be different in Jinhua and Landrace pigs. Up to now, little is known about the developmental changes of serum IGF-I, leptin, insulin, $\mathrm{T}_{3}$ and $\mathrm{T}_{4}$ levels in Jinhua pigs, nor the breed differences between Jinhua and Landrace pigs. Therefore, Jinhua and Landrace pigs with significant differences in growth rate and fat deposition were employed in the present study to investigate the age-related changes of serum IGF-I, leptin, insulin, $\mathrm{T}_{3}$ and $\mathrm{T}_{4}$ levels, the main effects of breed and age group, and their interaction were also investigated in this study.

\section{MATERIAL AND METHODS}

\section{Animals and diets}

This study was approved by the Institutional Animal Care and Use Committee of Zhejiang University. Purebred Jinhua and Landrace piglets were used (18 gilts of each breed, weaned at 28 days of age). The feeding experiment lasted 90 days after a 7-day of adaptation period. Jinhua and Landrace gilts were reared in the same conditions. All pigs had ad libitum access to an experimental diet and water via nipple drinkers. The experimental diets were formulated to meet the NRC 
(1998) nutrient requirements for the different growth phase. During the period from 28 to 125 days of age, the experimental diet offered to pigs is shown in Table 1.

Table 1. Ingredients and nutrients of the experimental diets

\begin{tabular}{|c|c|c|}
\hline Item & 28 to $80 \mathrm{~d}$ & 80 to $125 \mathrm{~d}$ \\
\hline \multicolumn{3}{|l|}{ Ingredients, $\mathrm{g} / \mathrm{kg}$} \\
\hline maize & 719.5 & 793.9 \\
\hline soyabean & 240.0 & 170.0 \\
\hline $\mathrm{CaHPO}_{4}$ & 17.0 & 12.0 \\
\hline limestone & 7.0 & 8.0 \\
\hline salt & 4.0 & 4.0 \\
\hline L-lysine.HCL & 2.5 & 2.1 \\
\hline Premix $^{1}$ & 10.0 & 10.0 \\
\hline \multicolumn{3}{|l|}{ Nutrients $^{2}$} \\
\hline $\mathrm{DE}, \mathrm{MJ} / \mathrm{kg}$ & 13.75 & 13.79 \\
\hline crude protein, $\mathrm{g} / \mathrm{kg}$ & 177.8 & 150.7 \\
\hline $\mathrm{Ca}, \mathrm{g} / \mathrm{kg}$ & 7.1 & 6.3 \\
\hline $\mathrm{P}, \mathrm{g} / \mathrm{kg}$ & 6.1 & 5.1 \\
\hline lysine, $\mathrm{g} / \mathrm{kg}$ & 9.6 & 7.7 \\
\hline
\end{tabular}

\section{Carcass fat contents}

The measurement of carcass fat content was made according to the methods of Xiao et al. (1999). Briefly, pigs were electrically stunned, exsanguinated, dehaired and eviscerated. The head was removed and the carcass was split longitudinally. After an overnight chilling at $4^{\circ} \mathrm{C}$, one half of the carcass was physically dissected into bone, muscle, fat and skin, and fat content was weighted to the nearest gram respectively. Carcass fat percentage was calculated by the formula: [(dissected yield - cold carcass weight $) \times 100]$.

\section{Blood sampling and serum analysis}

Six purebred gilts of each breed were slaughtered at 35, 80 and 125 days of age. All gilts were starved overnight $(12 \mathrm{~h})$ prior to sacrifice. Samples of blood were taken immediately, and blood was allowed to clot overnight at $4{ }^{\circ} \mathrm{C}$, serum was harvested following centrifugation and was stored at $-20^{\circ} \mathrm{C}$ until assay.

Serum concentrations of leptin were determined using a commercially available kit (Multispecies Radioimmunoassay Kit; Linco Research, St. Charles, 
MO). Validation of the assay for porcine serum has been previously reported (Qian et al., 1999). The assay sensitivity was $0.2 \mathrm{ng} / \mathrm{ml}$ and intra- and inter-assay coefficients of variation were 4 and $8 \%$, respectively.

Serum IGF-I concentrations were determined with RIA kit (Beijing North Institute of Biotechnology, Beijing, China) in a Camma-counter (Packard 8500; Packard Instrument Co., Downers Grove, IL, USA). The intra- and inter-assay coefficients were 3.3 and $7.8 \%$, respectively.

Serum $\mathrm{T}_{3}, \mathrm{~T}_{4}$ concentrations were measured with RIA kit (Beijing North Institute of Biotechnology, Beijing, China) in a Camma-counter (Packard 8500; Packard Instrument Co., Downers Grove, IL, USA). The intra- and inter-assay coefficients of variation were 5 and $10 \%$ for $\mathrm{T}_{3}, 5$ and $10 \%$ for $\mathrm{T}_{4}$, respectively.

Serum insulin concentration was measured with a RIA kit (Beijing North Institute of Biotechnology, Beijing, China) in a Camma-counter (Packard 8500; Packard Instrument Co., Downers Grove, IL, USA). The intra- and inter-assay coefficients of variation were 5 and $10 \%$, respectively.

\section{Statistical analyses}

Statistical analyses were performed using GLM procedures of SPSS 11.5. For all data, the model included the main effects of breed and age group, and their interaction. Comparison among age groups with the same breed uses one-way analysis of variance with age as the main effect. Differences among means were tested by Duncan's comparisons. And comparison between breed groups with the same age was determined by t-test. A significant level of 0.05 was used. Person correlations coefficients were used to determine the relationship between serum hormone levels and carcass fat content. All data are presented as mean $\pm \mathrm{SEM}$.

\section{RESULTS}

Carcass fat content. There were increases in carcass fat percentage $(\mathrm{P}<0.001)$ with increasing age. Jinhua gilts had greater carcass fat percentage $(\mathrm{P}<0.001)$ than Landrace gilts. But, there was not a significant interaction between breed and age and carcass fat percentage. In addition, as shown in Figure 1, the carcass fat percentage showed an age-dependent pattern. It was low at 35 days of age, followed by a significant stepwise increase in the two breeds from 35 to 125 days of age. Jinhua gilts had higher $(\mathrm{P}<0.05)$ carcass fat percentage than Landrace gilts, which resulted in a higher fat deposition rate in Jinhua gilts.

Serum leptin levels. Breed and age had effect on serum leptin levels $(\mathrm{P}<0.001)$, whereas, their interaction was not observed $(\mathrm{P}>0.05)$. As shown 
in Figure 2, the developmental change of serum leptin levels in Jinhua and Landrace gilts followed a similar age-dependent pattern. The serum leptin levels were low at 35 days of age, significantly increased at 80 days of age, and remained higher at 125 days of age. In addition, Jinhua gilts had higher serum leptin levels compared with Landrace gilts at 80 and 125 days of age $(\mathrm{P}<0.05)$.

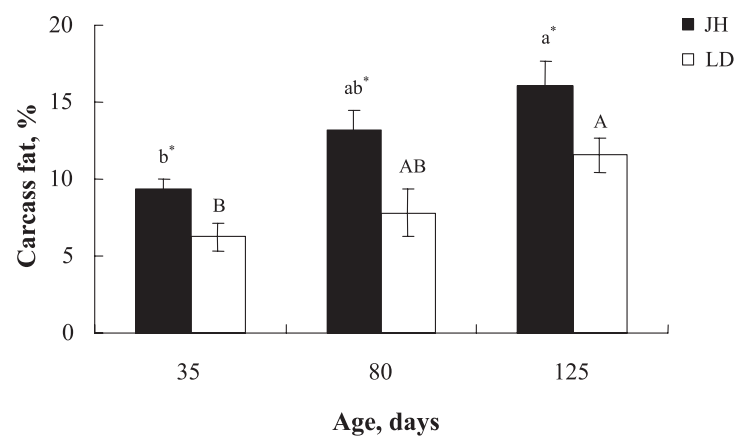

Figure 1. Developmental changes of carcass fat content in growing Jinhua (JA) and Landrace (LD) gilts. Mean values without a common superscript (capital letters for LD and small for JH) differ significantly between age; ${ }^{*} \mathrm{P}<0.05,{ }^{* *} \mathrm{P}<0.01$ indicating difference between breeds at the same age

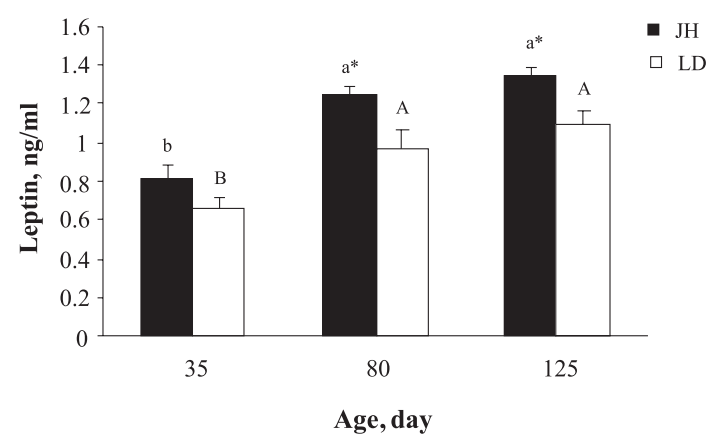

Figure 2. Developmental changes of serum leptin levels in growing Jinhua and Landrace gilts Explanation - see Figure 1

Serum IGF-I levels. Breed and age had effect on serum IGF-I levels $(\mathrm{P}<0.001)$, as shown in Figure 3. Age-related changes of the serum IGF-I levels followed same trends in the two breeds during the whole experiment. The serum IGF-I levels were low at 35 days of age, significantly increased at 80 days of age $(\mathrm{P}<0.05)$, and remained higher $(\mathrm{P}<0.01)$ at 125 days of age. In addition, serum IGF-1 levels were lower in Jinhua gilts compared with Landrace gilts at 35 days $(\mathrm{P}<0.01), 80$ days $(\mathrm{P}<0.05)$ and 125 days $(\mathrm{P}<0.05)$ of age. 


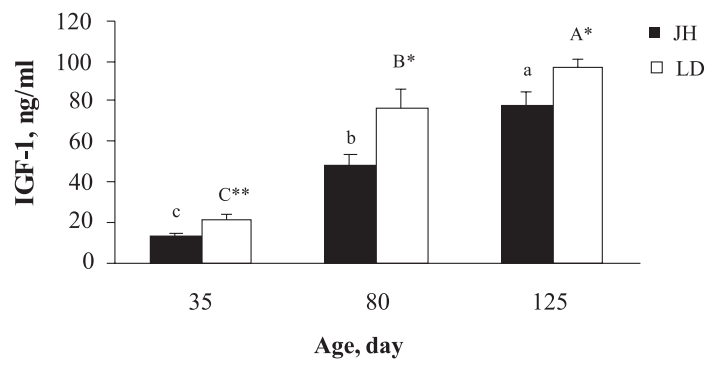

Figure 3. Developmental changes of serum IGF-I levels in growing Jinhua and Landrace gilts Explanation - see Figure 1

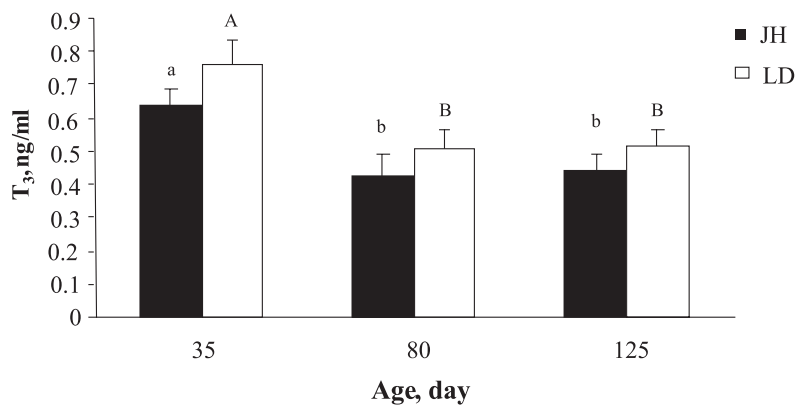

Figure 4. Developmental changes of serum $\mathrm{T}_{3}$ levels in growing Jinhua and Landrace gilts Explanation - see Figure 1

Serum $T_{3}$ and $T_{4}$ levels. Only age had effect on serum $\mathrm{T}_{3}$ levels $(\mathrm{P}<0.01)$. As shown in Figure 4, the developmental changes of serum $\mathrm{T}_{3}$ levels were identical in Jinhua and Landrace gilts. The serum levels of $T_{3}$ showed an age-dependent pattern. It was high at 35-day age, followed by a significant decrease at 80 days $(\mathrm{P}<0.05)$ of age, and remained a lower level in the two breeds on 125th day. However, the serum $\mathrm{T}_{3}$ levels did not differ significantly between the two breeds during the whole experiment.

Breed $(\mathrm{P}<0.01)$ and age $(\mathrm{P}<0.001)$ had effect on serum $\mathrm{T}_{4}$ levels. The developmental changes of the serum $\mathrm{T}_{4}$ levels followed same patterns in the two breeds during the study (Figure 5). The serum $\mathrm{T}_{4}$ levels were high at 35 days of age, markedly decreased at 80 days $(\mathrm{P}<0.05)$ of age, and remained lower at 125 days $(\mathrm{P}<0.05)$ of age. The Jinhua pigs had lower $(\mathrm{P}<0.01)$ serum $\mathrm{T}_{4}$ levels compared with Landrace at 80 days of age.

Serum insulin levels. Breed $(\mathrm{P}<0.001)$ and age $(\mathrm{P}<0.01)$ had effect on serum insulin levels. As shown in Figure 6, the developmental changes of serum levels of insulin are not identical in Jinhua and Landrace gilts. The serum insulin levels of Jinhua gilts significantly increased with age, while that of Landrace gilts remained 


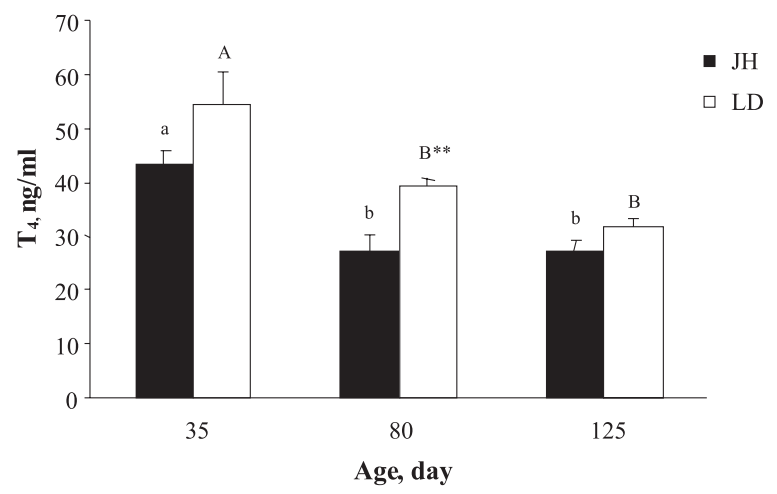

Figure 5. Developmental changes of serum $\mathrm{T}_{4}$ levels in growing Jinhua and Landrace gilts Explanation - see Figure 1

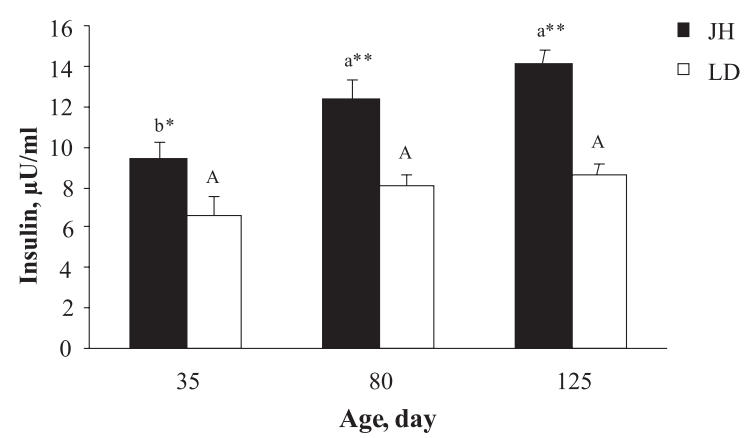

Figure 6. Developmental changes of serum insulin levels in growing Jinhua and Landrace gilts Explanation - see Figure 1

unchanged during the whole experiment. In addition, the Jinhua gilts had higher serum levels of insulin compared with Landrace gilts at 35 days $(\mathrm{P}<0.05), 80$ days $(\mathrm{P}<0.01)$ and 125 days $(\mathrm{P}<0.01)$ of age.

Correlation coefficients. As shown in Table 2, the carcass fat content were positively correlated $(\mathrm{P}<0.05)$ with serum leptin, IGF-I and insulin levels in Jinhua and Landrace gilts. Whereas, there was a negative correlation $(\mathrm{P}<0.05)$ between the carcass fat content and serum $\mathrm{T}_{4}$ levels in the two breeds. In addition, no correlation was observed between carcass fat content and serum $T_{3}$ levels $(\mathrm{P}>0.05)$. 
Table 2. Correlation coefficients ( $\mathrm{r}$ ) between carcass fat content and serum hormone levels in Jinhua and Landrace gilts

\begin{tabular}{lccccc}
\hline \multirow{2}{*}{ Item } & \multicolumn{3}{c}{ Carcass fat, \% } \\
\cline { 2 - 4 } \cline { 5 - 6 } & $\mathrm{r}$ & P-value & & $\mathrm{r}$ & Landrace \\
\cline { 2 - 3 } \cline { 5 - 6 } Leptin, $\mathrm{ng} / \mathrm{ml}$ & 0.567 & 0.014 & & 0.607 & 0.008 \\
IGF-I, ng/ml & 0.572 & 0.013 & & 0.578 & 0.012 \\
Insulin, $\mu \mathrm{U} / \mathrm{ml}$ & 0.482 & 0.043 & & 0.534 & 0.022 \\
$\mathrm{~T}_{3}, \mathrm{ng} / \mathrm{ml}$ & -0.422 & 0.081 & & -0.293 & 0.238 \\
$\mathrm{~T}_{4}, \mathrm{ng} / \mathrm{ml}$ & -0.541 & 0.021 & & -0.481 & 0.043 \\
\hline
\end{tabular}

\section{DISCUSSION}

Leptin is a paracrine functioning hormone produced by porcine adipose tissue (Ramsay et al., 1998) that can affect feed intake and energy metabolism, and subsequently act on the tissue to alter lipid accretion by altering lipolysis and lipogenesis (Ramsay, 2004). Serum letpin level is more highly correlated with fat deposition (Cameron et al., 2000), and serves as a signal reflecting the body fat content (Gill et al., 1997). Several reports demonstrated age-related changes of serum leptin concentrations in humans and rodents (Fried et al., 1998). The present study demonstrated for the first time, the developmental changes of serum leptin levels of Jinhua and Landrace gilts. The serum leptin levels increased with age in both breeds of pigs, and Jinhua gilts had higher leptin levels compared with Landrace gilts, which was positively correlated with carcass fat percentage. Our results are similar to reported by Qian et al. (1999) and Zhou et al. (2004), who observed that the age-dependent increase in circulating leptin levels and adipose leptin mRNA expression appears to depend largely on the increased body weight, fat content and adipocyte size. However, Laubiz et al. (2006) showed that significant difference in serum leptin concentrations among breeds was lack (Pietrain, Duroc and synthetic line 990). In addition, the serum leptin concentrations in Jinhua and Landrace gilts were lower than previous report value in pigs (Barb et al., 2001), it could result in the difference in age and fat content of pigs.

In mammals, the puberty onset is dependent on certain extent of body fat deposition (Zhou et al., 2004). Jinhua pigs with higher body fat content matures earlier than Landrace pigs (Xu,1994), which indicates a close relationship between fat deposition and sexual maturation. Leptin serves as a signal reflecting the body fat content (Gill et al., 1997) and a factor for initiating and maintaining normal reproductive functions, such as puberty attainment (Massimiliano et al., 2001).

Numerous studies established that elevated GH concentration could stimulate muscle growth and concurrently reduce fat deposition (Etherton, 2000). In the 
somatotrophic axis, GH can act in tissue directly on the cells itself or indirectly through the action of locally and systemically produced IGF-I (Florini et al., 1996). With respect to IGF-I, little is known about the effect of IGF-I on lipid metabolism in pigs. In the present study, the serum IGF-I levels were positively correlated with carcass fat content of pigs. The results are inconsistent with previous reports. Thompson et al. (1995) postulated that IGF-I mediates the effects of GH in lean tissue growth but not in fat deposition. Owens et al. (1994) reported no relationship between IGF-I concentrations in plasma and backfat depth in the finishing phase in pigs. However, elevated IGF-I could increase satellite cell (muscle precursor cell) proliferation and fusion with existing fibre (Holly and Hughes, 1994), which led to an increase in muscle protein accretion (Moss and LeBlond, 1971). The present study demonstrated for the first time, the developmental changes of serum IGF-I levels in growing Jinhua and Landrace gilts. The results are in agreement with previous reports that serum IGF-I levels increases with age from 6 to $18 \mathrm{wk}$ of age in pigs (Owens et al., 1994, 1999). Therefore, the age-dependent increase in circulating IGF-I levels appears to depend largely on the increased body weight, fat and lean tissue content.

Thyroid hormones are predominantly considered as hormones involved in the catabolic processes of lipids (Sheridan and Kao, 1998). Thyroid hormones influence all major metabolic pathways. Their most obvious and well-known action is an increase in basal energy expenditure obtained acting on protein, carbohydrate and lipid metabolism. With specific regard to lipid metabolism, thyroid hormones affect synthesis, mobilization and degradation of lipids, although degradation is influenced more than synthesis (Pucci et al., 2000). In this study, developmental changes of the serum $\mathrm{T}_{3}$ and $\mathrm{T}_{4}$ levels followed same trends in the two breeds. It was decreased with age during the whole experimental period. Our results are similar to what is reported by $\mathrm{Xu}$ (2002), who observed that serum $\mathrm{T}_{3}$ and $\mathrm{T}_{4}$ levels of Erhualian pig and Large White pig decreased with age from 30 to 120 days of age. In addition, serum $\mathrm{T}_{3}$ levels did not differ between two breeds, however, Jinhua gilts had lower $\mathrm{T}_{4}$ levels compared with Landrace gilts at 80 days of age. It indicates that increased serum $\mathrm{T}_{4}$ concentration was a contributor to promoted lipolysis in pigs. These may explain breed differences of serum $\mathrm{T}_{4}$ concentrations in Jinhua and Landrace gilts.

Adipose tissue is the major site of de novo lipid synthesis in pigs (O'Hea et al., 1969) and glucose is the primary carbon source of lipogenesis. Isotope kinetics studies have shown that $>40 \%$ of whole-body glucose turnover can be used by adipose tissue for de novo lipogenesis in $80 \mathrm{~kg}$ pigs (Dunshea et al., 1992). Insulin is mainly to stimulate glycogen synthesis, fatty deposition and inhibit gluconeogenesis (Ehterton et al., 1982; Chung et al., 1983). Up to now, little is known about the developmental changes of serum insulin levels in pigs. 
The present study demonstrated, for the first time, the age-related changes of serum insulin levels of Jinhua and Landrace gilts. Similar results were reported between Erhualian and Large White pigs by Xu (2002), who observed that serum insulin levels of Erhualian increased from 20 to 120 days of age, however, those of Large White pigs remained unchanged. In addition, our studies showed that Jinhua gilts had higher serum insulin levels compared with Landrace gilts, which indicated there was a difference in carbohydrate and lipid metabolism between the two breeds. However, other reports showed that serum insulin levels did not differ between pigs of different breeds (Xu, 2002).

\section{CONCLUSIONS}

It was found that serum IGF-I, leptin, insulin, $\mathrm{T}_{3}$ and $\mathrm{T}_{4}$ levels were influenced by breed and age of pigs, but their interaction was not found. The developmental changes of serum IGF-I, leptin, insulin, $\mathrm{T}_{3}$ and $\mathrm{T}_{4}$ levels followed breed-specific patterns. Serum IGF-I, leptin and insulin were positively correlated with carcass fat content, while there was negative correlation between serum $\mathrm{T}_{4}$ levels and carcass fat content in Jinhua and Landrace gilts. In addition, no correlation was observed between serum $\mathrm{T}_{3}$ levels and carcass fat content. The breed differences of serum IGF-I, leptin, insulin and $\mathrm{T}_{4}$ levels may contribute to the different phenotypes in adipose tissue deposition.

\section{REFERENCES}

Barb C.R., Barrett J.B., Kraeling R.R., Rampacek G.B., 2001. Serum leptin concentrations, luteinizing hormone and growth hormone secretion during feed and metabolic fuel restriction in the prepuberal gilt. Domest. Anim. Endocrinol. 20, 47-63

Cameron N.D., Penman J.C., Mccullough E., 2000. Serum leptin concentration in pigs selected for high or low daily food intake. J. Genet. Res. 75, 209-213

Chilliard Y., 1993. Dietary fat and adipose tissue metabolism in ruminants, pigs and rodents: a review. J. Dairy Sci. 76, 3897-3931

Chung S.C., Meserole V.K., Etherton T.D., 1983. Temporal nature of insulin binding and insulinstimulated glucose metabolism in isolated swine adipocytes. J. Anim. Sci. 56, 58-62

Dunshea F.R., Harris D.M., Bauman D.E., Boyd R.D., Bell A.W., 1992. Effect of porcine somatotropin on in vivo glucose kinetics and lipogenesis in growing pigs. J. Anim. Sci. 70,141-151

Etherton T.D., 2000. The biology of somatotropin in adipose tissue growth and nutrient partitioning. J. Nutr. 130, 2623-2625

Etherton T.D., Walker O.A., 1982. Characterization of insulin binding to isolated swine adipocytes. Endocrinology 110, 1720-1724

Florini J.R., Ewton D.Z., Coolican S.A., 1996. Growth hormone and the insulin-like growth factor system in myogenesis. Endocr. Rev. 17, 481-517 
Fried S. K., Ricci M. R., Russell C. D., 1998. Regulation of leptin production in human. J. Nutr. $130,3127-3131$

Gill M.S., Toogood A.A., O’Neill P.A., 1997. Relationship between growth hormone (GH) status, serum leptin and body composition in healthy and GH deficient elderly subjects. Clin. Endocrinol. 47, 161-167

Holly J.M., Hughes S.C., 1994. Measuring insulin-like growth factors: why, where and how?. J. Endocrinol. 140, 165-169

Laubitz D., Jankowska A., Nieminuszczy J., Wrzesiński M., Jaworski A., Romanowicz K., Matyjek R., Grzesiuk E., Zebrowska T., Zabielski R., 2006. Pancreatic secretion differs according to the genotype of growing pigs. J. Physiol. Pharmacol. 57, 677-689

Massimiliano C., Elisa F., Andrea M.I., 2001. Leptin in reproduction. Trends Endocrinol. Metab. $12,65-72$

Moss F.P., LeBlond C.P., 1971. Satellite cells as the source of nuclei in muscles of growing rats. Anat. Rec. 170, 421-436

O'Hea E.K., Leveille G.A., 1969. Significance of adipose tissue and liver as sites of fatty acid synthesis in the pig and efficiency of utilization of various substrates for lipogenesis. J. Nutr. 99, 338-344

Owens P.C., Campbell R.G., Francis G.L., Quinn K.J., 1994. Growth hormone, gender and insulinlike growth factors: Relationship to growth performance in pigs. J. Anim. Sci. 72, Suppl. 1, 235 (Abstr.)

Owens P.C., Gatford K.L., Walton P.E., Morley W., Campbell R.G., 1999. The relationship between endogenous insulin-like growth factors and growth in pigs. J. Anim. Sci. 77, 2098-2103

Pucci E., Chiovato L., Pinchera A., 2000. Thyroid and lipid metabolism. Int. J. Obesity Metab. Disord. 24, Suppl. 2, S109-S112

Qian H., Barb C.R., Compton M.M., Hausman G.J., Azain M.J., Kraeling R.R., Baile C.A., 1999. Leptin mRNA expression and serum leptin concentrations as influenced by age, weight and extradiol in pigs. Domest. Anim. Endocrinol. 16, 135-143

Ramsay T.G., 2004. Porcine leptin alters isolated adipocyte glucose and fatty acid metabolism. Domest. Anim. Endocrinol. 26, 11-21

Ramsay T.G., Yan X., Morrison C., 1998. The obesity gene in swine: Sequence and expression of porcine leptin. J. Anim. Sci. 76, 484-490

Sheridan M.A., Kao Y.H., 1998. Regulation of metamorphosis-associated changes in the lipid metabolism of selected vertebrates. Amer. Zool. 38, 350-368

Thompson J.L., Butterfield G.E., Marcus R., Hintz R.L., Van L.M., Ghiron L., Hoffman A.R., 1995. The effects of recombinant human insulin-like growth factor-I and growth hormone on body composition in elderly women. J. Clin. Endocrinol. Metab. 80, 1845-1852

Xiao R.J., Xu Z.R., Chen H.L., 1999. Effects of ractopamine at different dietary protein levels on growth performance and carcass characteristics in finishing pigs. Anim. Feed Sci. Tech. 79, 119-127

Xu Q.F., 2002. Regulation and expression of target genes for growth hormone action in liver and muscle of pigs. DD Dissertation, Nanjing Agricultural University, Nanjing (China), pp. 47-51

Xu Z.R. (Editor), 1994. Modenrn Nutrition of Swine. Zhejiang University Press, Hangzhou (China), pp. $57-72$

Zhang Y.Y., Proenca R., Maffei M., Barone M., Leopold L., Friedman J.M., 1994. Positional cloning of the mouse obese gene and its human homologue. Nature 372, 425-432

Zhou J., Zhao R.Q., We X.H., Xia D., Xu D., Chen J., 2004. Developmental patterns of serum leptin level, leptin gene expression in adipose tissue and $\mathrm{Ob}-\mathrm{Rb}$ gene expression in hypothalamus of Erhualian and Large White pigs. Sci. China, Ser. C Life Sci. 47, 190-196

Zhou J., Zhao R.Q., Wei X.H., Xia D., Xu D., Chen J., 2003. The developmental patterns of GHR, IGF-I and IGF-IR gene expression in adipose tissue of Erhualian and Large White pigs (in Chinese). Acta Gen. Sinica 30, 657-662 